\title{
Financial Market Reform in Transition Economies
}

\author{
Kim Hawtrey
}

F INANCIAL market reform is vital for the development and successful transition of the former socialist economies, because of the pivotal role that the modern monetary sector plays in attracting committed capital and in facilitating enterprise.

Yet financial reform, represented by deep asset markets and modernised banking institutions, remains far from complete in Russia and the other East European countries. Monetary policies are unpredictable and there is inadequate infrastructure to define and support regularised trading in financial instruments. Key factors in a mature financial system, such as availability of credit, efficient banking services, and secure contract law, are frequently absent. As a consequence, real investment (especially by foreigners) is being seriously affected by the presence of irregularities in trading between various financial assets, and an unstable and frequently unworkable banking system.

For instance, Alexander Khandruyev, Deputy Chairman of the Russian central bank, acknowledged in January 1995 that there were signs of a 'banking crisis' in the wake of the Black Tuesday rouble crisis of October 1994 when the currency slumped by 27 per cent against the US dollar (to 3,926 roubles per dollar) in a single day. Following this, the bank attempted to impose several control measures: a rise in the refinancing rate, a 30 per cent cut in banks' open currency positions, and heavy raising of commercial banks' reserve requirements. In August 1995, the interbank market was frozen for several days, banks were shut and interest rates shot up to 1,000 per cent.

Policy in these countries therefore needs urgently to address the operation of banks and financial markets. Many banks in the transition economies are unprofitable and are not yet functioning effectively in the role of allocating credit; they are still largely state owned, and the majority of assets are still controlled by banks created in the communist era. For example, 70 per cent of bank assets in Hungary are concentrated in four state banks; in Poland only three of nine banks proposed for privatisation in 1991 have been sold off; and Hungary's three largest banks (Budapest Bank, Magyar Hitel Bank, Kereskedelmi Bank) are still not privatised. In addition, financial services markets, sucl as those for company shares, insurance, bonds, bills of exchange, derivatives and foreign currency, suffer from inadequate

Kim Hawtrey is Lecturer in the School of Economic and Financial Studies at Macquarie University. 
securities laws in what amounts to a legal vacuum. I arge and variable fluctuations are not unusual in listed share prices, which in the space of twelve months typically rise or fall by more than two or three times. This twin uncertainty - about legal rights and market values - is currently impeding the creation of deep equity and debt securities markets.

In turn, this hampers wider industrial enterprise. Under central planning, the mechanisms for credit and value transfer were centralised and closely administered, often involving barter or inter-regional trade agreements conducted by government agencies rather than banks. The move toward a market approach therefore represents a major shift, with large adjustments required of both government and industry. Many economic agents and government officials have little experience of financial instruments, credit, contracts, free banking, and the like. Consequently, governments continue to finance unviable enterprises, and industry lacks access to basic value-adding monetary mechanisms. Without laws to enforce bills or loans, firms camnot obtain inputs on credit because suppliers do not have legal recourse to recover monies unpaid. Hence the urgent need to develop an institutional framework for financial transactions that will encourage the money and credit markets to function properly.

\section{A Micro-Financial Reform Agenda}

To improve the operation of financial markets, policymakers need to address a range of issues.

Tax reform. Russian banks face a tax rate of 43 per cent, compared with only 35 per cent for industrial enterprises. In general, taxes at present tend to be arbitrary, changeable and too high. Many taxes apply not to net profits, but to gross sales; normal business expenses such as advertising are often not deductible. As noted by Pardy (1992), countries that have in the past favoured directed credit and state ownership of commercial banks tend to have tax systems that discriminate in favour of bank savings at the expense of securities vehicles, and bank loans at the expense of public capital raisings. Such tax biases distort allocative efficiency.

The monetary value transfer system.' This ranges from the simplest level, such as secure postal services and couriers, to the more complex level of the bank chequeclearing mechanism and electronic money transfers. If these are not functioning, the community will have an incentive to resort to barter. Failure to develop an adequate international payments system has already worsened the transition economies' debt problem, and fostered inferior barter trade. In particular, bank cheque-

\footnotetext{
${ }^{1}$ The essential elements of a non-cash interbank payments system include flexible methods by which customers may make payment for goods (such as credit card, EFT, debit card, and so on), effective arrangements for the interbank clearing of payments instructoons (including rapid sorting, accounting and transporting, both centralised and bilateral), and settlement processes (which refers to the exchange of final value between financial institutions to extinguish net obligations upon clearing).
} 
clearing in Russia and other transition economies can take between four and eight weeks, which is very costly under hyperinflation.

Securities legislation. The securities law is presently underdeveloped. Russia, for instance, urgently needs legislation to cover certificate of title, insider dealing, registration, corporate disclosure, purchases by foreign investors, the role of brokers and fund managers, and so on. The new Russian Securities Commission, appointed in January 1995, is a positive step, but is only a beginning. An example of the type of problem that needs to be addressed is the burdensome re-registration procedures involved in share trading: to evade this, many companies have issued shares that carry the company's name as the registered owner, allowing buyers freely to trade the stock as if it is a bearer security rather than inscribed. One serious problem with this is the scope it provides for tax evasion.

Transferable property rights. In a market economy, where transactions occur on voluntary basis, both parties to a transaction must be assured they will fully own their asset (and fully relinquish their liability). An example of policy failure here is that Russian law currently does not automatically confer on a mining company the right to mine ore it discovers: others are allowed to bid for it, even though they have played no part in discovering it. Without guaranteed property rights, bank lending policies and risk guidelines are rendered meaningless.

In this regard, the first part of the Russian Civil Code (proclaimed in December 1994) is a vital first step. It repealed two inferior (1990) laws (On Enterprises, On Property) as from 1 January 1995. The second part of the Code, which will include provisions on securities, is scheduled for later in the decade. As a minimum it needs to include exclusivity and inalienability of legal property title. Attempts to introduce a fully articulated land code have so far not been forthcoming, hampering banks' ability to underwrite development projects.

Bankruptcy law. The essence of bankruptcy law is the ranking of various classes of creditors' claims against the bankrupt debtor, so that as the defunct company is liquidated, its assets are pooled and competing claims are satisfied in order from highest to lowest priority. In accepted Western law, 'secured' claims (those contractually backed by collateral) are usually ranked above all other claims, giving creditors possession of collateralised assets before secondary creditors can be paid. However, under Section 64 of Part One of the Russian Civil Code, secured claims are subordinated to two other classes of creditor: those seeking compensation for personal injury, and workers seeking unpaid wages or royalties. As a result, traditional secured creditors now have no recourse or control in respect of such commitments entered into by the debtor after a loan is contracted.

\section{The Pace of Financial Reform}

Two broad questions are raised by the process of financial reform: the pace at which it is implemented, and the need, if any, for a fixed sequence of reforms. In 
this section it is argued that the case for rapid financial restructuring with minimal sequencing is stronger than that for gradual reform.

Most transition economies have adopted a gradualist approach to reforming their financial systems, apparently because of the strain that 'shock therapy' could place on the domestic political economy, leading to instability and unpredictability. Such instability, it is said, could create excessive hardship, unemployment and loss of markets. It is sometimes argued that the old rigidities are so deeply ingrained that they will take a generation to change; after all, the financial systems of Western countries took decades to evolve. Thus, many of the restructuring economies have attempted bite-size reforms, one at a time.

However, evidence from the five years or more of gradualism suggests that the experiment has failed. Table 1 provides a broad-based comparative assessment of the progress of reform in the various east and central European transition economies. Some caution needs to be exercised. Data for those countries may be subject to statistical irregularities. Further, it may in some cases be too early, as well as inappropriate for analytical reasons, to draw strong conclusions from macroeconomic data, which are subject to a multitude of influences apart from the banking sector. In particular, aid assistance received from the West varies markedly from country to country; susceptibility to Russian influence differs widely; and resource endowments are unequal. Notwithstanding these caveats, however, the table provides a point of reference for the discussion that follows.

The five columns on the left side of the table show the speed with which transition economies have undertaken reform since 1990. The three columns on the right hand side show some macroeconomic indicators that, over time, would be expected to respond to bank reform. Overall, Table 1 suggests there is a broad correlation between the speed of banking reform in a transition country and its early macroeconomic performance. The faster reformers, by and large, are experiencing better (non-negative) growth in real output and lower inflation rates. Most telling, however, are the figures on long-term capital inflow, which are positive for the fast reformers and negative or low for Russia and the other slow-reform countries. While many other factors affect these macroeconomic outcomes, the data tend to vindicate early bank reform.

The basic problem for the slow reformers is that 'bad money drives out good': so long as the old political connections remain intact, there is a strong inertia in favour of vested interests; and so long as the bureaucracy still plays a major role in credit allocation, it is difficult for commercial banks and market forces to gain a foothold. Given continued access to state credit, underpinned by soft budget constraints or barter, the 'hard credit' of a truly marketised banking system remains in a subordinated role to the former, less demanding avenue preferred by borrowers. 
Table 1

Finance sector transition: progress indicators

\begin{tabular}{|c|c|c|c|c|c|c|c|c|}
\hline \multirow[t]{3}{*}{ counTrY } & \multicolumn{5}{|c|}{ Stance on reform } & \multicolumn{3}{|c|}{ Effocts of reform } \\
\hline & (1) & (2) & (3) & (4) & (5) & (6) & (7) & (8) \\
\hline & $\begin{array}{l}\text { Size of } \\
\text { GNP, } \\
1993 \text { : } \\
\text { US } \$ \text { bn }\end{array}$ & $\begin{array}{l}\text { Pace } \\
\text { of } \\
\text { bank } \\
\text { reform }\end{array}$ & $\begin{array}{l}\text { Two- } \\
\text { tier ba- } \\
\text { nking }\end{array}$ & $\begin{array}{l}\text { Bank } \\
\text { privati- } \\
\text { sation }\end{array}$ & $\begin{array}{l}\text { Legal } \\
\text { frame- } \\
\text { work }\end{array}$ & $\begin{array}{l}\text { GNP } \\
\text { growth } \\
1994 \\
(\%)\end{array}$ & $\begin{array}{l}\text { Inflation } \\
1994 \\
(\%)\end{array}$ & $\begin{array}{l}\text { Net av- } \\
\text { erage } \\
\text { annual } \\
\text { foreign } \\
\text { capital } \\
\text { inflow } \\
1990-94 \\
(\% \text { GNP) }\end{array}$ \\
\hline Armenia & 2.4 & slow & late & med. & * & 3.0 & 2670.3 & n.a. \\
\hline Azerbaijan & 5.4 & slow & late & med. & * & -21.9 & 1266.3 & n.a. \\
\hline Belarus & 29.3 & slow & late & med. & * & -21.5 & 1940.7 & n.a. \\
\hline Bulgaria & 10.1 & med. & late & low & * & -2.4 & 76.0 & 2.1 \\
\hline Czech Rep. & 20.7 & med. & mid & med. & 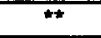 & 2.2 & 9.5 & 4.0 \\
\hline Estonia & 4.9 & fast & early & high & *** & 6.0 & 50.8 & 3.2 \\
\hline Hungary & 34.2 & $\begin{array}{l}\text { fast } \rightarrow \\
\text { slow }\end{array}$ & early & low & ** & 3.8 & 19.1 & 7.1 \\
\hline Kazakhstan & 26.5 & slow & late & med. & $\star$ & -25.0 & 2061.2 & n.a. \\
\hline Kyrgyzstan & 3.9 & slow & late & med. & * & -26.5 & 155.5 & n.a. \\
\hline Latvia & 5.3 & fast & early & high & $\overline{t+\pi}$ & 0.1 & 30.0 & 2.9 \\
\hline Lithuania & 4.9 & $\begin{array}{c}\text { med.I } \\
\text { fast }\end{array}$ & early & med. & $m$ & 2.0 & 69.0 & $\overline{3.8}$ \\
\hline Moldova & 4.7 & slow & late & med. & - & -22.2 & 259.4 & n.a. \\
\hline Poland & 86.6 & fast & early & med. & 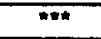 & 5.6 & 31.9 & 2.3 \\
\hline Romania & 25.9 & $\begin{array}{l}\text { slow/ } \\
\text { med. }\end{array}$ & mid & low & ** & 2.2 & 139.2 & 3.0 \\
\hline Russia & 347.9 & slow & late & med. & $=$ & -14.3 & 356.7 & -1.0 \\
\hline Slovakia & 10.3 & med. & mid & med. & $m$ & 4.2 & 11.7 & 0.2 \\
\hline Tajikistan & n.a. & slow & late & med. & 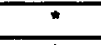 & n.a. & n.a. & n.a. \\
\hline Turkmenistan & n.a. & slow & late & med. & * & n.a. & n.a. & n.a. \\
\hline Ukraine & 114.0 & $\begin{array}{c}\text { slow } \rightarrow \\
\text { fast }\end{array}$ & late & med. & * & -26.7 & 870.4 & n.a. \\
\hline Uzbekistan & 21.2 & slow & late & med. & - & -4.5 & 234.9 & n.a. \\
\hline
\end{tabular}

Notes: The former Yugoslavia has been omitted from the table due to the effects of internal conflict. Columns: (1) aggregate GNP in 1993, in US\$ billions; (2) author's overall assessment of the general rate of progress in bank reform; (3) 'two-tier banking' refers to the separation of central banking institutions from commercial banking institutions; (4) proportion of the banking sector transferred from state to private ownership; (5) stars broadly indicate how advanced each country is in implementing essential legislation for banking and securities markets; (6) 1994 annual real percentage growth in GNP; (7) 1994 annual inflation rate as measured by percentage change in the GNP deflator (but consumer price index for Czech Republic); (8) average annual long-term foreign capital inflow over the five years 1990-94, expressed as a ratio of GNP; net long-term capital inflow comprises changes (excluding valuation adjustments) in residents' long-term foreign liabilities minus their foreign assets; Czech Republic includes medium- as well as long-term capital. 
In 1994 the Ukraine realised this and began to move faster towards full financial reform. Prior to that, the economy was deteriorating: productivity had fallen 40 per cent, and yet at the same time credit was ballooning, the currency was devalued, and interest rates were negative in real terms. Then in 1994 the central bank, led by first deputy chairman Vladimir Stelmach, implemented a radical reform package. Although problems remain, interest rates in after-tax terms are now positive, inflation is lower and foreign investors are responding positively. (This happened too late to show up in Table 1.)

A crucial point to recognise is that the transition economies are capital hungry. They are 'shortage economies' not only in the sense that basic consumer products such as milk and bread are in short supply, but in the financial sense that capital is extremely scarce. Comparisons with the development of Western economies are instructive at this point: the West may not have grown its modern banking institutions rapidly, but nevertheless has always mobilised capital. It is misleading to focus simply on the institutional evolution of banking in the West, because the real question is its historic ability to mobilise capital for investment. This is what is lacking in the transition economies - which is why capital market reform is urgent. The tooslow pace of financial sector reform is starving these economies of essential capital; and when reform progresses unevenly, as it has, the cost in terms of lost opportunities mounts up. The political honeymoon is dissipated, and the economic instability in the currency (and hyperinflation) destabilise the economy. When interest rates are not positive in real terms, saving is not adequately encouraged.

A central argument is that true enterprise (real sector) reform will not be possible in the absence of banking (finance sector) reform. In the wake of 70 years of Soviet rule, the banking systems in Central and East European economies are sometimes even less sophisticated than those in developing countries. Banks and enterprises are choked with old debts and outdated procedures. If enterprises are to be marketised, they must be placed on a laard-budget, 'active', best-practice financial footing. In turn, this can occur only if they are dealing with a liberalised banking system that imposes the disciplines of the marketplace. This implies that the banks need to be reformed as early as possible.

The effect of the pace of reform on small business should not be ignored. Pleskovic (1993) argues that delays discourage small-scale entrepreneurs, inhibit the entry of new firms, and retard the transition process by placing a burden on household living standards through high taxes. Financial costs, especially interest rates, are a major determinant of the vitality of the small enterprise sector.

Estonia, Latvia and Lithuania have all used shock therapy, and are probably the leading examples of the success of this approach. Since winning independence five years ago, Estonia embarked on rapid financial reform and has transformed itself into one of the fastest growing economies in Europe. Per capita foreign investment

${ }^{2}$ To put this in perspective, Russia's current debt stands at around US\$120 billion, and to date it is yet to sign agreements with creditors on its former USSR liabilities. The IMF stand-by loan amounts to only US\$6.5 billion. 
is high (comparable with Poland and Hungary, two further examples of rapid reform), the unemployment rate is only 2 per cent, and inflation is under control.

Hungary's reforms until 1994 were mostly driven by the finance minister, Laszlo Bekesi. His resignation in January 1995, however, signalled some loss of resolve in Hungary, with Prime Minister Horn appearing now to opt for less budget deficit reduction and slower privatisation. For example, in January 1995 the privatisation of the state-owned chain Hunger Hotels was reversed after it had earlier been approved by the State Privatisation Agency. This backsliding carries the very real risk of alienating foreign investors who have so far injected over US $\$ 8$ billion into Hungary. Indeed, in 1995 the Hungarian central bank had to dip into its foreign reserves; from 1 February 1995 reserve requirements were increased for commercial banks, and official bank reserve requirements were raised from 12 per cent to 14 per cent. To reduce credit pressures, the National Bank of Hungary in early 1995 also had to eliminate its currency swap and one-month repurchase facilities, and increase the base lending rate by three points (to 28 per cent). This has led to a fall in stock-market prices.

The clear lesson of the Hungarian case is that markets are sensitive to the pace of reform: markets responded positively to the early years of Hungarian reform, but have become cautious since late 1994, when the pace of financial reform slowed. (This market sensitivity factor is also highlighted by recent developments in Vietnam, where the government is implementing a 'big bang' approach to reform, and is gaining a very warm response from investors.) The relative success of early shock therapy in Hungary, Poland and Estonia indicates that bold strikes taken earlier rather than later yield the greatest gains.

Another significant argument for rapid reform is the potential benefit to the central government budget in the form of increased revenue. This happens in three ways. First, stronger market activity produces higher general business taxation revenues. Second, privatisation of banks generates income that goes directly into central revenue and can be used to repay debts. Third, channelling household savings through formal bank accounts rather than informal alternatives creates a new base for taxation. By speeding up the improvement in the revenue base, rapid financial reform is an aid to fiscal improvement.

It has been argued by McKimnon (1991) that banks should be the last part of the economy to be reformed, on the grounds of risks from lack of supervision and poor controls. This quality-control issue is not insignificant, as illustrated by a recent episode in China where weak controls led to a financial crisis. Yet it does not justify postponing financial reform; rather, it shows the need for an active prudential central bank and proper financial legislation. McKinnon's argument (1991:138) is that 'the sorry history of bank lending in partially liberalised regimes - such as Yugoslavia, Poland, Hungary and the PRC in the 1980s - shows the severe moral hazard from state banks overlending to enterprises that local or central governments

\footnotetext{
3 In a single day in February 1995, the Shanghai Intennational Securities firm was pushed to the brink of bankruptcy through bond market futures, causing the authorities to close the market temporarily.
} 
wish to promote'. As loss-making enterprises were the main absorbers of credit, according to McKinnon, in the early stages enterprises should be restricted to selffinance and non-bank capital. Quite apart from the fact that episodes such as the 1995 Barings Bank collapse in the UK occur also in high-quality Western systems, the problem with McKinnon's argument is that those early liberalisation episodes in the 1980s were not proper tests of deregulated transition banking. Rather, they demonstrate the folly of liberalisation that is only partial. An equally plausible conclusion is that the bad loan problem arose because banking marketisation was incomplete: the state was still the dominant player, and reform was too slow. This allowed loss-makers continued access to credit precisely because the banking system was not able to perform its function as an optimal credit-allocation mechanism.

The major reforms of the financial system - securities markets legislation, bank prudential regulation, marketisation of financial institutions - can and should be implemented largely concurrently, subject to resource constraints and central coordination, along with macroeconomic policy discipline. The evidence suggests that a clean break with the past, and rapid modernisation, will produce the best results for intenational integration with global capital markets and for domestic economic advance. More than the real sector, the financial sector closely approximates the textbook notion of a perfect market in the sense that it does not easily tolerate barriers, non-neutralities (that is, an unlevel playing field) and dividing lines. Capital flows easily across borders and between locations, implying that capital global suppliers will not readily meet the massive funding needs of the capital-scarce economies in the presence of existing anomalies.

\section{Managing Reform}

Sequencing. One of the effects of adopting a fast rate of financial sector reform is to concertina the various steps involved. But if the reform agenda is conceived in terms of a series of distinct steps, the ideal sequence would be the following. First, commercial banking is separated from central banking, and market-based financial legislation is established (including prudential rules). Second, basic infrastructure, such as skilled banking personnel (especially supervisory) and standardised payment systems, needs to be put in place. Third, competitive banking markets are created through privatisation of existing state-owned banks, demonopolisation of banking, and controlled entry of foreign banks. Fourth, a plan for managing the most pressing old debts (possibly including equity swaps or discounted write-offs) is implemented, so that the marketised banks and enterprises can be free to develop their balance sheets. ${ }^{5}$ And fifth, education in credit assessment (for banks) and use of banking services (for the public) is conducted.

\footnotetext{
${ }^{4}$ Notably, the World Bank granted a US\$558 million credit facility to Russia on 28 April 1995 to fund projects to upgrade the tax system, and train financial staff.

${ }^{5}$ One estimate suggests that around 75-80 per cent of total bank loans in transitional economies are unlikely to be repaid (Caprio \& Levine, 1992:18).
} 
Nevertheless, rapid reform implies little or no sequencing. If changes are made in a piecemeal fashion, the interdependence of financial markets may be ignored, which can result very quickly in rate of return distortions and unjustified economic rents. Capital requires equal access to competing uses, and economic theory tells us that a 'general equilibrium' approach to reform requires that this principle should be adhered to from the outset.

A case in point is Latvia, where simultaneous progress in structural adjustment of both real and financial sectors has been significant. Alongside price liberalisation and small-business development, banking industry privatisation is well advanced and programs have been set up to train the public in finance. The govenment has established the Latvian Investment Agency as a one-stop shop to provide private investors with easy access to information on banking laws, securities regulations and investment opportunities. Demonopolisation has progressed steadily from the beginning. Lithuania, after a slightly slower start, has gained similar momentum. The separation of commercial banking from central banking occurred early in the reform process; and a program to restructure and privatise the three largest stateowned banks has been implemented. New central and commercial bank laws have been introduced, including prudential requirements on bank balance sheets. Current efforts are focused on improving credit-assessment skills and refining securities legislation.

State and private ownership. Related to the issue of the sequence of bank reforms is privatisation and the optimal mix of state and private ownership. Privatising exSoviet banks with their balance sheets unreconstructed can do more harm than good. The newly privatised bank will carry a heavy burden of old debt which is unlikely to be repaid, and will hang like a millstone around the neck of private enterprise. Profit-making borrowers could end up subsidising older loss-making ones. One solution is for the government to accept on to its own books some of the outstanding bank claims, thus allowing the new institution to start with a cleaner slate. This could be accomplished by replacing the bank claims with government paper. Although simply an accounting transaction, this step has positive implications for the speed and efficiency of privatisation, because the way in which the authorities treat past debts will affect the rate and sustainability of economic liberalisation.

Discriminatory incentives for reform. A further question is whether the government, having decided on a strategy of rapid banking reform, should actively intervene in favour of the securities markets. For example, it might offer a package of discriminatory measures, including tax incentives, designed to accelerate banking evolution. This might include such measures as waiving securities registration fees, regulating broker charges, capping the interest rate charged on loans, exempting securities from capital gains tax, giving tax breaks to foreign investors, requiring all firms over a stipulated asset size to list on the stock exchange, subsidising the transaction costs associated with equity raisings, and so on. But although superficially attractive, especially as it operates on the supply side rather than the demand side, 
this approach should be rejected in most circumstances. Using the taxation system or budget expenditures in such a fashion violates the principle of neutrality by fostering uneven and biased economic development. Once such irregular measures become entrenched, they are difficult to revoke.

Asset concentration. State ownership (both direct and indirect) and the oligopolistic market structure of banking remain an obstacle to marketisation. Bank assets are still concentrated in a few institutions; this forms a barrier to entry by new banks, reduces genuine competition and hampers attempts to improve operational efficiency. State ownership of commercial banks causes potential conflict of interest between central bank prudential policy and political or state interests.

One way of combating asset concentration is to disaggregate the balance sheet of the few, large existing banks into many, smaller institutions. But this can spread resources and expertise too thin, so losing the benefits of economies of scale. A second approach is to foster competition by region, giving a degree of control and autonomy to various provinces and even municipalities; at the same time, some central functions and controls can be maintained in the interests of stability. A third method is the partial or full privatisation of existing state-owned banks. This has the benefit of exposing rigid institutions to the disciplines of free enterprise. The obstacles here, however, include the absence of suitable buyers (especially if the bank carries a lot of debt from the past) and the clash between the old Soviet culture and the new business culture. A fourth approach is to introduce foreign banks, hoping that they will do quickly what ex-Soviet banks are able to do only slowly: modernise the banking environment. On 27 April 1995, Russia's President Yeltsin signed a decree lifting all previous restraints on foreign bank operations in Russia for those granted licences. However, this raises the issue of foreign control over the domestic banking system. The ideal solution is likely to involve a mix of the above approaches.

A related principle is the separation of financial and industrial enterprises, unlike the so-called 'wild cat' banking that has occurred in Russia, where a financial service institution springs up that is backed by an ordinary company (operating with a soft budget constraint). A recent example is the Samara Region Financial Industrial Company, to be named Volzhskie Automobile 2000 (Volga Cars). It comprises the AutoVAZ joint stock company, the AutoVAZ bank, the Samara branch of the Inkombank, and 24 ex-defence enterprises of the region, which will provide the production capacities for manufacturing cars. Such companies are a recipe for financial disaster and fraud, overturning as they do the arms-length relationship between commercial banks and the firms to which they lend that is a key principle of

\footnotetext{
${ }^{6}$ However, a positive step the govenment might take with less distortionary eflect is the bearing of risk in the early stages of market development. An example is the 'national bond fund' established by China in February 1995 to protect investors against losses on turbulent bond markets. Investors can buy shares in the pool of bonds rather than directly purchasing bonds on their own; this aids liquidity and reduces individual risk.
} 
Westem financial structures. This does not rule out trade or inter-enterprise credit, but keeps it separate from the financial sector proper.

\section{Conclusion}

Financial sector reform is an urgent priority in transition economies. If monetary liberalisation lags behind enterprise liberalisation, old credit channels will continue to dominate new ones. Budget constraints at the microeconomic level will remain soft. In the presence of a distorted interest rate, the relationship between existing wealth and future income flows will be inefficient, and credit will not be allocated optimally. Without a secure liquid investment asset bearing a positive real rate of interest, enterprises will elect to hold excessive levels of inventories, and individuals will not save.

The stress being currently caused by financial delinquency in the shortage economies is such that the whole development process is critically contingent upon fixing it. Dornbusch and Reynoso (1993:65) state that in development, "financial factors are important, but probably only when the financial instability becomes a dominant force in the economy'. This thresloold has been well and truly exceeded in transition economies. Poor finance leads to inflation and credit and external bottlenecks, which in turn paralyse macroeconomic policy and retard growth. Savings are underworked, misallocated and incorrectly rewarded: a core illness that has widespread real effects in what are essentially capital-deficient economies.

Should the Western economic powers play a targeted supportive role in promoting rapid financial sector reform? If so, at what level? It is tempting to suggest that the IMF and/or World Bank could assist in the privatisation of banks, by selectively underwriting old Soviet debts that the state must write down if bank privatisation is to accelerate. But the debts are huge; and such Western assistance could create an incentive for superficiality on the part of receiving governments. But the West can help to market the debt at discounted prices and undertake equity swaps; moreover, Western banks can offer to help with their existing stock of expertise.

The present need is to attract the 'second wave' of institutional investors, entrepreneurs, and savers. The first post-1989 wave brought an initial influx of foreign investment and an early batch of private small business ventures, driven by curiosity, optimism and the honeymoon effect. However, the next plase will need to be based more squarely on financial fundamentals, where players and new entrants can be convinced of the long-term potential of these markets. Getting the financial infrastructure right is a necessary condition for marketised enterprise investment and trade; and the ability of these countries to stabilise their financial systems will be a major factor in the success of their economic transition. 


\section{References}

Caprio, G. \& R. Levine (1992), Reforming Fünance in Transitional Socialist Economies, World Bank, Washington DC, April (Working Paper WPS 898).

Dombusch, R. \& A. Reynoso (1993), 'Financial Factors in Economic Development', ch. 4 in R. Dombusch (ed.), Policymaking in the Open Eronomy, Oxford University Press, New York.

McKinnon, R. (1991), The Order of Economic Liberalisation: Financial Control in the Transition to a Market Economy, Johns Hopkins University Press, Baltimore.

Pardy, R. (1992), Institutional Reform in Emerging Securities Maskets, World Bank, Washington DC, May (Working Paper WPS 907).

Pleskovic, B. (1994), Financial Policies in Socialist Countries in Transition, World Bank, Washington DC, January (Policy Research Working Paper 1242).

United Nations (1995a), World Economic and Social Survey 1995, New York.

- (1995b), Economic Bulletin for Europe, vol. 46, Geneva.

World Bank (1995), Thends in Developing Countries, Washington DC.

This article is based on a paper that the author presented at the University of Gomel, Belarus, on 25 January 1995. The author is grateful to the staff of the Economics Faculty at the University of Gomel and to three anonymous referees for helpful comments, but is responsible for any errors. Research leading to the paper was carried out while the author was visiting the University of Gomel, whose assistance is gratefully acknowledged. 